\title{
Sorrel (Rumex acetosa L.): Not Only a Weed but a Promising Vegetable and Medicinal Plant
}

\author{
Helena Korpelainen ${ }^{1,2}$ - Maria Pietiläinen ${ }^{1}$ \\ ${ }^{1}$ Department of Agricultural Sciences, University of Helsinki, Viikki Plant Science Centre, P.O. Box 27 \\ (Latokartanonkaari 5), FI-00014 Helsinki, Finland \\ ${ }^{2}$ Author for Correspondence; e-mail: helena.korpelainen@ helsinki.fi \\ Published online: 12 August 2020
}

(C) The Author(s) 2020

\begin{abstract}
Sorrel (Rumex acetosa L.) is a perennial, dioecious herb occupying a variety of habitats. Sorrel has been utilized as a wild gathered plant for thousands of years and as a cultivated plant for centuries. Primarily roots but also other tissues have been used in folk remedies since ancient times. In recent investigations, different phytochemical and pharmacological activities of Rumex have been analyzed, and many bioactive compounds have been detected. Sorrel is also a tasty plant and its leaves are a good source of macronutrients and micronutrients. However, the presence of high levels of oxalic acid reduces the bioavailability of some minerals, especially calcium, when using uncooked plant parts. Further investigations on different sorrel compounds are needed to show their true effect. It is beneficial that sorrel is easily propagated and there are no serious insect or disease problems. A few types of $R$. acetosa seeds are presently available commercially, including wild types and a few cultivars.
\end{abstract}

Keywords Breeding $\cdot$ Medicinal herb $\cdot$ Oxalic acid $\cdot$ Rumex $\cdot$ Sorrel $\cdot$ Vegetable

\section{Introduction}

Rumex is a genus with about 200 species of annual, biennial and perennial herbs, rarely shrubs, that belong to the buckwheat family (Polygonaceae) and are distributed in Europe, Asia, Africa and North America, primarily in the northern hemisphere (Flora Europaea 1993; Mabberley 2008). Some of them are considered nuisance weeds, while others are used for their edible leaves or medicinal properties. The present review concentrates on the sorrel $R$. acetosa L., also called common sorrel, English sorrel, sheep's sorrel, red sorrel, sour weed and field sorrel. The common names of Rumex species are varied and even confusingly overlapping among species. For scientific names, Latin is the primary language. The etymological origin of the genus name Rumex probably comes from the Greek word for spear or dart, due to the spear shaped leaves of the plant (Liddell and Scott 1940). Another theory has been presented by Saleh et al. (1993): evidently, the Romans used to suck the plants to allay thirst, and the name Rumex is thus derived from the Latin word for suck. The species name acetosa is 
derived from acetum, the Latin word for vinegar, referring to the sharp taste, comparable to the name and taste of sheep's sorrel R. acetosella (Parker 2018).

$R$. acetosa is a wind-pollinated vigorous perennial, dioecious herb occupying a wide variety of habitats, but being especially common to grasslands, pastures and disturbed land (Korpelainen 1991). It grows to a height of 30-80 cm, the stem being glabrous (Flora Europaea 1993; Mabberley 2008). The leaves are large, hairless, and ovate in outline and have characteristic, pointed basal leaf lobes. The stalk of basal leaves is longish, while stem leaves are almost stalkless. The small pinkish flowers are unisexual (either male of female). The fruit is a triangular achene. R. acetosa is found throughout Europe from the northern Mediterranean coast to the north of Scandinavia and parts of Central Asia, and it occurs as an introduced species in parts of Australia and North America (Flora Europaea 1993; Mabberley 2008). Based on the present knowledge, the species $R$. acetosa involves thirteen subspecies and five varieties (WFO 2020). A life history capable of responding to different environmental demands is necessary for plants, which possess a wide geographic distribution or inhabit otherwise variable habitats. The response may operate through genetic differentiation among plants occurring in different habitats or through phenotypic plasticity. Sorrels have been shown to exhibit a very plastic morphology and a good amount of genetic diversity (Korpelainen 1992, 1993, 1999; Ye et al. 2012), and this may help to explain how they can exist in a wide range of environments.

On the basis of a wide coverage of literature on sorrel ( $R$. acetosa), the present review will compile scientific information on the basic biology, wide variety of traditional and present uses, and further use potential, as well as on the chemical and pharmacological properties of this species. We aim to highlight not only the many benefits of sorrel cultivation but also the concerns linked to its use. Our objective is to create a comprehensive review of the knowledge of $R$. acetosa that can guide further basic and applied research on this plant.

\section{Sex Determination and Life History}

The presence of sex chromosomes is not common in plants (Korpelainen 1998), where the majority of species are hermaphroditic. Among angiosperms, about $10 \%$ of species are dioecious (Lloyd, 1982), but only rarely they possess sex chromosomes (Grant et al. 1994; Parker 1990). R. acetosa is one of those plant species that has sex chromosomes, namely $2 \mathrm{n}=12+\mathrm{XX}$ in females and $2 \mathrm{n}=12+\mathrm{XY} 1 \mathrm{Y} 2$ in males (Kihara and Ono 1923; Ono 1935; Parker and Clark 1991; Shibata et al. 1999, 2000). The Y chromosomes play no role in sex determination, but rather it is the ratio of $\mathrm{X}$ chromosomes to autosomes, which is decisive for sex determination, i.e., individuals with X: A ratios of $\leq 0.5$ are male, while individuals with $X$ : A ratios of $\geq 1.0$ are female. Individuals with intermediate X: A ratios (polyploids and aneuploids) produce intersex or hermaphrodite flowers. Mariotti et al. (2009) have shown that the rapid accumulation and expansion of DNA satellites have contributed to an increase in the size and differentiation of the nonrecombining $\mathrm{Y}$ chromosome that has no function in sex determination. Later, to gain insight into the molecular mechanism of sex determination, Manzano et al. (2017) generated a cDNA library enriched in genes specifically or predominantly expressed in female floral buds. They demonstrated the presence of a flower-specific gene 
designated FEM 32 and showed that its transcripts accumulate much more in female flowers than in male flowers. Manzano et al. (2017) considered likely that FEM 32 functions in $R$. acetosa by arresting stamen and pollen development during female flower development.

Navajas-Pérez et al. (2005) have estimated that dioecy in the genus Rumex developed about $16 \mathrm{Ma}$, and the acetosa clade with the sex chromosome system originated 12-13 Ma ago. The results of Navajas-Pérez et al. (2005) further supported the view that sex determination based on the balance between the number of $\mathrm{X}$ chromosomes and the number of autosomes has evolved secondarily from male-determining $Y$ mechanisms and that the multiple sex chromosome system, XX/XY1Y2, derived twice from an $\mathrm{XX} / \mathrm{XY}$ system. Occasionally, intersex inflorescences have been observed (Ainsworth et al. 2005). A genetic, PCR-based method has been developed to reveal the sex of $R$. acetosa at any life stage (Korpelainen 2002), not just at sexual maturity, when dimorphic flower structures are present.

In dioecious plants, males and females may have different ecological requirements or tolerances, and natural selection can act differently on them. Consequently, the environment differentially influences male and female performance (i.e. fitness), which may lead to biased sex ratios. The cost of reproduction of female plants often exceeds that of male plants, because, besides flowers, females produce seeds and fruits. Potentially, the greater female reproductive effort could result in reduced female growth and/or survival. However, the sex ratios of $R$. acetosa are typically female-biased (Korpelainen 1991, 1992). It is notable that since it has a high capacity for vegetative reproduction, the cost difference between the sexes may not be as significant as in strictly sexually reproducing species, and there may be other mechanisms that contribute to the sex ratio bias, e.g., higher male mortality (Korpelainen 1991). Based on a genetic sex identification method, Korpelainen (2002) discovered that sex ratios are still about 1:1 at the seed stage, while there are also observations supporting the view that female-biased sex ratios of $R$. acetosa are determined prezygotically to some extent (Błocka-Wandas et al. 2007).

Genotypic differences, maternal effects, phenotypic plasticity and the quality of the environment all influence a plant's life history characteristics. Korpelainen (1992) has observed that the males of $R$. acetosa allocate more resources to reproduction during the time of flower production than do females, whereas females invest more in reproduction during seed production. Thus, males and females show different life history strategies. Altogether females, which are taller and may have a higher resource threshold for the occurrence of sexual reproduction, allocate both a higher amount and a higher proportion of energy to reproduction than do males (Korpelainen 1992). Yet, the operational sex ratios are strongly female-biased. Perhaps, with a greater size, $R$. acetosa females are better buffered against the resource demands that sexual reproduction creates, and this may lead to a lower female mortality (Korpelainen 1992). Despite differences in life history traits, little sexual dimorphism has been observed in the phenological traits, such as flowering onset, peak, duration and proportion of newly opening flowers (Matsuhisa and Ushimaru 2019). Such lack of phenological differences enhances synchronous flowering with the opposite sex. 


\section{Wide Variety of Uses}

Wild plants have been harvested in European settlements at least from the Neolithic and Mesolithic periods. Sorrel seeds and charred plant parts indicating food processing have been found in settlement sites throughout Europe (Andersen 1990; Kotzamani and Livarda 2018; Kubiak-Martens 1999; Vanhanen and Pesonen 2016). Wild plants have traditionally been gathered mainly by women and children in many rural areas throughout the world, usually casually and sometimes more systematically. In today's rural societies this practice has been declining, as people increasingly get their foods from the supermarkets. However, during recent years, new trends have been emerging and wild plant harvesting has become more popular, specifically as an urban pastime. Urban wild food harvesting seems to engage people from all walks of life. Today's urban foragers include both men and women, as well as diverse ethnic, economic and social groups. Wild food harvesting is often casual, although small-scale cultivation of wild plants is getting more common. Urban dwellers increasingly enjoy spending time in the nature, and they like to learn about old traditional practices and are willing to utilize wild resources in cuisine (Abbet et al. 2014; Etkin 1994; McLain et al. 2014; Pardo de Santayana et al. 2007). Such newly developed interests in nature may improve appreciation for biodiversity and, consequently, contribute to the conservation of nature as well as to the diversification of crop plants.

Among Rumex species, sorrel, $R$. acetosa has the greatest use potential. It is a delicious plant, which provides good, months-long harvests of edible leaves that have quite distinctive acidic taste caused by oxalic acid. Sorrel has been utilized for thousands of years, and used as food in diverse dishes, as herbal preparations for various purposes, and as a source of different colors of dyes (Bello et al. 2019; Couplan 2009; Dogan et al. 2015; Sun et al. 2015; Vasas et al. 2015) (Table 1). Relatives in the genus Rumex that are used as food, although less frequently, include, e.g., sheep sorrel $R$. acetosella, often considered a weed but having edible small leaves, red-veined sorrel $R$. sanguineus, being actually more ornamental than flavorful, spinach dock (also known as patience dock, garden patience or herb patience) $R$. patientia, growing much taller and having a quite pleasant flavor, spinach rhubarb $R$. abyssinicus, a tall plant with leaves that can substitute for spinach and ribs like rhubarb, and French sorrel R. scutatus, used mainly in salads and soups or as a spinach substitute (Mekonnen et al. 2010; Vasas et al. 2015). In some regions, the leaves of other Rumex species, such as $R$. alpinus, $R$. hymenosepalus, $R$. gracilescens and $R$. pseudonatronatus are utilized as foods, mainly in the form of sour soups, sauces and salads (Abbet et al., 2013; Ahmad et al. 2016; Bello et al. 2019; Dogan et al. 2015; Mekonnen et al. 2010; Vasas et al. 2015).

There have been numerous ethnobotanical and ethnopharmacological reports dealing with the occurrence and traditional uses of Rumex species (e.g. Abbasi et al. 2015; Alzoreky and Nakahara 2001; Dogan et al. 2015; Mekonnen et al. 2010; Vasas et al. 2015) (Table 1). As a cultivated plant, sorrel, R. acetosa has been produced for centuries, and it is a quite widely used herb in native cuisine throughout Europe and parts of Asia, such as India and Vietnam and parts of Africa, such as Ethiopia and Cameroun, where it is grown as a garden herb or vegetable. It is commonly combined with other greens and eaten raw or cooked in soups, stews and pastries. Sorrel is widely mentioned in gardening and recipe books because of its distinctive sour taste, which is 


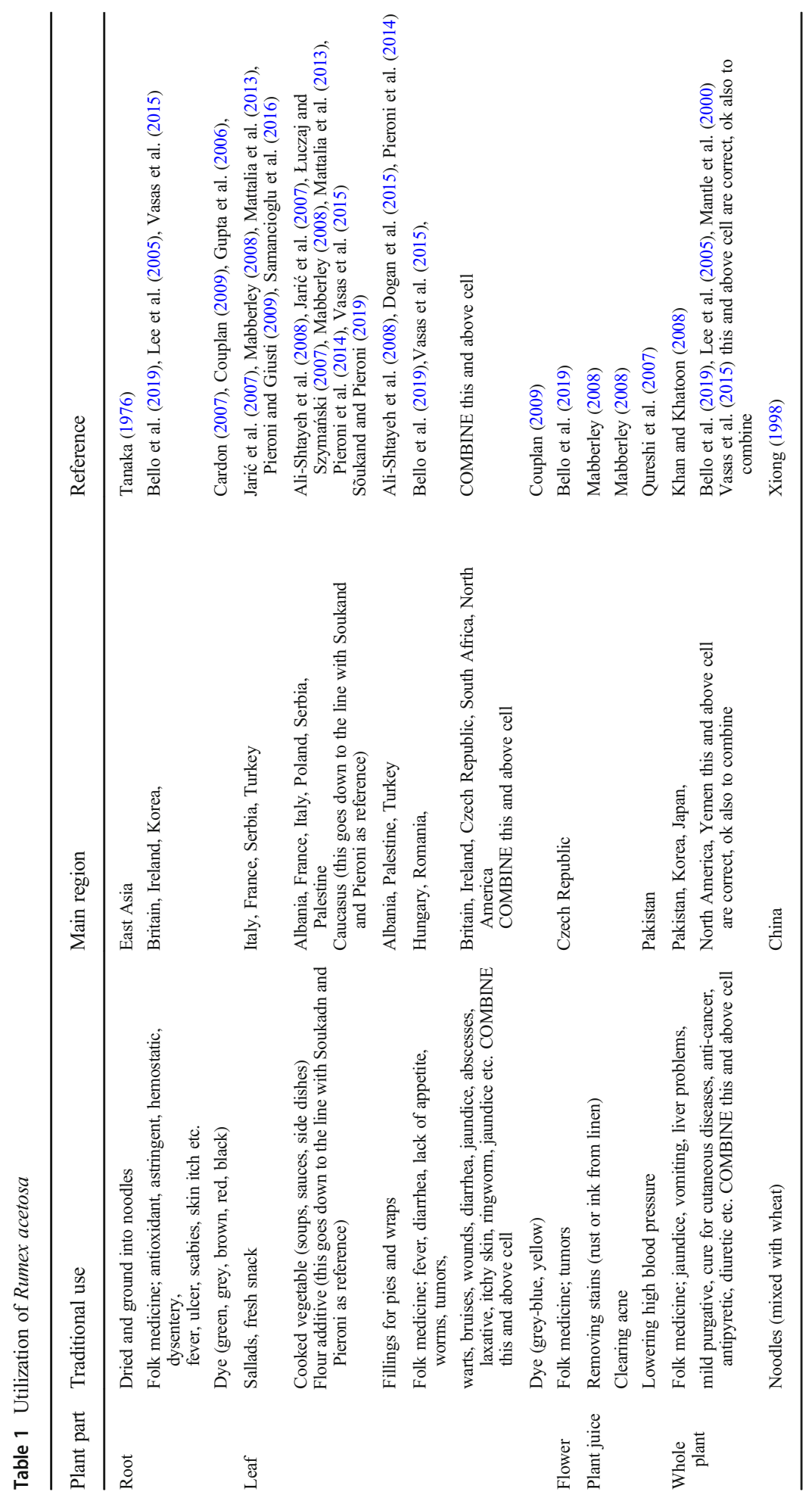


attributed to its high oxalic acid content. The tangy, acidic, sour-lemony flavor of sorrel blends well with a variety of ingredients, such as meat, cheese and milk. Sorrel sprouts and young immature leaves have a more subtle flavour and so are suitable for addition to salads and sandwiches. The more mature leaves are normally cooked and added to soups and stews and used to make sauces. Although $R$. acetosa is the most commonly used edible Rumex species, some food experts prefer less acidic French sorrel (R. scutatus) for culinary purposes.

Primarily roots but also other tissues of many species belonging to the genus have been reported to have various biological activities. They have been used in folk remedies from ancient times as anti-inflammatory, antioxidant, diuretic, antimicrobial, antihypersensitive, diuretic, analgesic, antiviral and anti-fungal agents to treat various health disorders, such as diabetes, constipation, infections, diarrhea, oedema, jaundice, scurvy, and liver and gallbladder disorders (Bae et al. 2012; Demirezer et al. 2001; Gescher et al. 2011; Kucekova et al. 2011; Lee et al. 2005; Taylor, 1996; Vasas et al. 2015; Wegiera et al. 2007). The antioxidant capacity of sorrel is reported to be approximately the same as in Japanese green tea (Alzoreky and Nakahara 2001). The flowers and rhizomes contain compounds that are suggested to have tumor arresting effects (Kucekova et al. 2011; Lee et al. 2005; Tamokou de Dieu et al. 2013). Traditionally, water from boiled sorrel has been used to wash chicken pox sores, boils, shingles-afflicted skin, poison ivy rashes, blisters, acne and other skin sores. It is supposed to ease pain, relieve itches and speed up the healing process (Table 1). Drinking sorrel water flavored with a bit of honey was believed to bring down a fever and help clear sinus infections (Bello et al. 2019).

\section{Chemical and Pharmacological Properties}

Based on the traditional knowledge, different phytochemical and pharmacological activities of $R$. acetos $a$ and other species in the same genus have been studied, including its chemical constituents, pharmacological activities, toxicity and safety. A range of promising medical and other new uses have been recognized (Table 2). A number of bioactive compounds have been detected in phytochemical investigations conducted on Rumex species. The aerial parts contain several flavonoids and polyphenols with antioxidant capacity, while its rhizomes are rich in anthraquinones and polysaccharides suggested to be responsible for, e.g., its antitumor effect (Bicker et al. 2009; Lee et al. 2005). Other isolated bioactive compounds involve emodin, naphthalenes, stilbenoids, triterpenoids, carotenoids, geranin, tannins, vanillic acid, corilagin, gallic acid, sinapic acid and pyrogallol. Bello et al. (2019) mention that over 50 chemical compounds have been isolated from the species.

Sorrel leaves are a good source of macronutrients and micronutrients, and it has been suggested that sorrel leaves could be used as an economic source of plant-based protein (Ladeji and Okoye 1993). However, the presence of high levels of the anti-nutritive factor, oxalic acid, reduces the bioavailability of some minerals, especially calcium, thus causing mineral deficiencies and other serious problems (calcium oxalate stone formation in kidneys, decreased iron absorption). Rhubarb grown primarily for its fleshy leafstalks is another example of a vegetable that contains considerable levels 
Table 2 Promising medical and other uses of Rumex acetosa

\begin{tabular}{|c|c|c|c|}
\hline Studied use/effect & Plant part & $\begin{array}{l}\text { Bioactive chemicals, } \\
\text { possible pathways }\end{array}$ & Reference \\
\hline $\begin{array}{l}\text { Antimutagenic, tumor } \\
\text { growth arresting, } \\
\text { apoptosis }\end{array}$ & Aerial parts & $\begin{array}{l}\text { Anthraquinones (esp. } \\
\text { emodin) }\end{array}$ & $\begin{array}{l}\text { Lee et al. (2005), Wegiera et al. } \\
\quad \text { (2012) }\end{array}$ \\
\hline $\begin{array}{l}\text { Positive nutrient and weight } \\
\text { gain }\end{array}$ & Leaf & Amino acids, minerals & Ladeji and Okoye (1993) \\
\hline $\begin{array}{l}\text { Antiproliferative (tumor } \\
\text { growth inhibition) }\end{array}$ & Flowers & $\begin{array}{l}\text { Phenolic compounds } \\
\quad \text { (flavan-3-ols) }\end{array}$ & Kucekova et al. (2011) \\
\hline $\begin{array}{l}\text { Antibacterial, cytotoxic, } \\
\text { antitumor }\end{array}$ & Leaf & $\begin{array}{l}\text { Silver nanoparticles } \\
\text { synthesized with leaf } \\
\text { extract }\end{array}$ & Kota et al. (2017) \\
\hline Vasorelaxation & Aerial parts & NO production & Sun et al. (2015) \\
\hline Antihypertension & Leaf & $\begin{array}{l}\mathrm{NO} \text { and COX enzyme } \\
\text { inhibitors and vasodilator }\end{array}$ & Qamar et al. (2018) \\
\hline Antioxidant activity & Leaf & Not known & $\begin{array}{l}\text { Alzoreky and Nakahara (2001), } \\
\text { Bae et al. (2012) }\end{array}$ \\
\hline Antiviral (HSV-1 virus) & Aerial parts & $\begin{array}{l}\text { Flavan-3-ols, oligomeric } \\
\text { proanthocyanidins }\end{array}$ & Gescher et al. (2011) \\
\hline $\begin{array}{l}\text { Anti-inflammatory } \\
\text { (periodontitis) }\end{array}$ & $\begin{array}{l}\text { Aerial parts } \\
\text { Aerial parts }\end{array}$ & $\begin{array}{l}\text { Galloylated } \\
\text { proanthocyanidins }\end{array}$ & $\begin{array}{l}\text { Beckert \& Hensel (2013) } \\
\text { Schmuch et al. (2013) }\end{array}$ \\
\hline $\begin{array}{l}\text { Influenza prevention these } \\
\text { lines should be in two } \\
\text { cells }\end{array}$ & two cells & $\begin{array}{l}\text { Galloylated } \\
\text { proanthocyanidins two } \\
\text { cells }\end{array}$ & Derksen et al. (2014) two cells \\
\hline Gastiritis, gastric ulcer & Leaf & Anthraquinones & Bae et al. (2012) \\
\hline $\begin{array}{l}\text { Antioxidant capacity, } \\
\text { biomatrix synthesis }\end{array}$ & & Iron oxide nanoparticles & Makarov et al. (2014) \\
\hline $\begin{array}{l}\text { Viral infections, acute viral } \\
\text { rhinosinusitis }\end{array}$ & Whole plant & Not known & $\begin{array}{l}\text { Glatthaar-Saalmüller et al. } \\
\text { (2011), Jund et al. (2012) }\end{array}$ \\
\hline $\begin{array}{l}\text { Nitrogen removal from } \\
\text { eutrofic waters }\end{array}$ & Whole plant & $\begin{array}{l}\text { Stimulating, e.g., nitrogen } \\
\text { bacteria growth }\end{array}$ & Zhou et al. (2012) \\
\hline $\begin{array}{l}\text { Emesis, gastrointestinal } \\
\text { motility disorders }\end{array}$ & Green parts & $\begin{array}{l}\text { Activation of muscarine } \\
\text { receptors, } \mathrm{Ca}^{2+} \text { blockage }\end{array}$ & $\begin{array}{l}\text { Hussain et al. (2015), Khan and } \\
\text { Khatoon (2008) }\end{array}$ \\
\hline $\begin{array}{l}\text { Astringent (diarrhoea, skin } \\
\text { irritations),infections }\end{array}$ & Aerial parts & Tannins & Bicker et al. (2009) \\
\hline $\begin{array}{l}\text { Possible cytotoxicity against } \\
\text { cancer }\end{array}$ & & $\begin{array}{l}\text { Stimulation of phagosytosis, } \\
\text { C3 activity }\end{array}$ & Ito (1986) \\
\hline Anti-inflammatory & Whole plant & Radical scavenging activity & Bae et al. (2012) \\
\hline $\begin{array}{l}\text { Antioxidant activity, } \\
\text { Alzheimer's disease }\end{array}$ & & $\begin{array}{l}\text { Scavenging of } \mathrm{ABTS}^{+} \text {or } \\
\mathrm{O} 2^{-} \text {radicals in vitro }\end{array}$ & Mantle et al. (2000) \\
\hline $\begin{array}{c}\text { Aluminium resistance, } \\
\text { phytoremediation }\end{array}$ & Whole plant & $\begin{array}{l}\text { High tolerance of toxic } \\
\text { metal ions }\end{array}$ & $\begin{array}{l}\text { Ernst et al. (2004), Tolrà et al. } \\
\text { (2005), Wang et al. (2003) }\end{array}$ \\
\hline
\end{tabular}

of oxalic acid. The risk of consuming foods high in soluble oxalates has been well documented (Noonan and Savage 1999; Tuazon-Nartea and Savage 2013).

Oxalate accumulation is affected by different factors, such as soil conditions, climate, species or cultivar and plant age. Tuazon-Nartea and Savage (2013) 
investigated the oxalate content of the leaves and stems of green and variegated cultivars of $R$. acetosa. The larger, more mature leaves of both cultivars contained higher levels of total, soluble and insoluble oxalates than other tissues. The stems also contained considerable levels of oxalates. However, the oxalate content varied considerably between cultivars, and even plants with quite low oxalate contents maintained their characteristic sour taste. In fact, other organic acids than oxalates can cause sour plant taste as well (Pereira et al. 2013). Yet, it was recommended that raw sorrel leaves should be consumed only occasionally or in small quantities as a delicacy because of their unique taste rather than as a significant part of the diet. On the other hand, the products made from sorrel leaves are less of a problem as they contain lower levels of oxalates. Tuazon-Nartea and Savage (2013) and Bello et al. (2019) have showed that cooking reduces the oxalic acid concentration of $R$. acetosa to a negligible amount. In addition, the oxalate contents can be lowered through selection breeding and appropriate choice of cultivars.

Aluminium toxicity is considered a major abiotic stress factor in low $\mathrm{pH}$ soils. $R$. acetosa is a pseudometallophyte that has been identified in several metal contaminated sites and it is well adapted to acid mineral soils with high availability of phytotoxic aluminium ions (Ernst et al. 2004; Tolrà et al. 2005; Wang et al. 2003). Aluminium resistance in $R$. acetosa implies both an exclusion of $\mathrm{Al}$ from root tips and tolerance to high $\mathrm{Al}$ concentrations in tissues. Citrate in roots and phenolics in shoots may bind aluminium into non-toxic forms. Anthraquinones, as strong antioxidants, may play a role in a general defence response to the root stress. Based on the existing tolerances, there may be potential to use sorrel for phytoremediation, i.e., for using living plants to clean up soil with hazardous contaminants.

\section{Use Potential and Cultivation}

It is clear that further investigations on different sorrel compounds are needed to show their true effect and provide scientific evidence for the medicinal effects of sorrel preparations and to aid the discovery of novel therapeutics and drug discovery. However, the use and cultivation potential of sorrel as a vegetable that provides a nice citrusy flavor to a variety of dishes has been proven (e.g. Jarić et al. 2007; Mattalia et al. 2013; Pieroni et al. 2014). Especially the leaves are a good addition to diets despite the presence of somewhat harmful oxalic acid in fresh plant material (Tuazon-Nartea and Savage 2013). A disadvantage is that the leaves lose quality quickly once harvested, which probably is a reason for sorrel being only rarely sold in markets. Therefore, a viable option would be to grow sorrel in containers that offer added longevity and marketability. Recently, Ceccanti et al. (2020) investigated the suitability of hydroponically grown Rumex acetosa as fresh-cut produce. They discovered that during postharvest storage in plastic boxes sorrel leaves maintained their nutraceutical value quite well. Yet, Ceccanti et al. (2020) emphasized the need for further research to standardize the yield and the nutraceutical content of this species.

$R$. acetosa is a perennial herb with long roots and smooth, arrow-shaped leaves that grow from a center rosette, and it will grow tall flower stalk as the temperature warms (Korpelainen 1993). Sorrel has preference for well-drained soil in full sun to partial shade. It is susceptible to damage from slugs and aphids, but there are no serious insect 
or disease problems (www.rhs.org.uk). It is easy to propagate in the garden by dividing the roots or by sowing seeds directly in the soil (H. Korpelainen, pers. obs.). Although sorrel tolerates moderate drought, it performs best when the soil is evenly moist. Once planted, sorrel requires little care to produce masses of leaves $(\mathrm{H}$. Korpelainen, pers. obs.). It can be grown as a potherb as well. Clipping leaves for cooking throughout the growing season enhances the growth of the plant. When the plant produces flower stalks in mid-summer, the whole plant should be cut back to encourage new leaf growth instead of setting seeds. Young leaves are best for culinary uses, either raw or cooked, since older leaves can be bitter and tough, yet usable for cooking (Nedelcheva 2013; Pardo de Santayana et al. 2007). Typically, the large, juicy leaves are boiled like spinach for a hot side dish of tasty greens topped with butter and salt.

A few types of $R$. acetosa seeds are available commercially, including wild types and a few cultivars. The best known cultivars are 'Belleville' and 'Profusion' (Weaver 2000). 'Belleville' is probably the oldest and most famous one having its origin in the late 1600's, when French gardeners decided to start to improve the flavor and texture of the leaves of wild sorrel. It was domesticated in France during the 1730s and its large, pale green leaves are still a classic ingredient in French cuisine. 'Belleville' seeds are commonly available and it is a very productive easily grown cultivar. Another comparable commercially available cultivar is 'Blonde de Lyon'. On the other hand 'Profusion' is an unusual patented variety, introduced in 1993, which does not flower or produce seeds at all. The leaves are round, dark green and more succulent than most other $R$. acetosa leaves. 'Profusion' sorrel can be increased only vegetatively by division or cuttings. It produces tender, fleshy leaves all season, long after standard varieties turn tough and bitter. It also makes a great ornamental border plant because it grows in attractive compact mounds of about 20-25 cm. In addition to these, the Royal Horticultural Society of England (www.rhs.org.uk) lists some garden varieties, such as Rumex acetosa subsp. acetosa 'Saucy'.

\section{Conclusions}

The present study introduces the biology of sorrel, $R$. acetosa and reviews scientific knowledge of its chemical and pharmacological properties, and highlights the traditional and present use as well as further potential as a cultivated or wild collected plant. Sorrel is an underutilized plant with considerable potential for greater use as food, medicinal herb and even as a plant for phytoremediation. Thus, this species deserves more attention in both basic and applied research, and in plant production. Our attempt is to increase interest in research, cultivation and utilization of sorrel. At the present, sorrel is largely consumed through wild foraging or growing in home gardens. However, there is potential for much greater commercial use. Sorrel is a vigorous and healthy plant, for which a viable production option would be to grow it in containers that would offer added longevity and marketability. If that was done in greenhouses, year-round production would be possible in diverse climates. Breeding effort could be aimed at developing different looking and tasting varieties, along with a lower oxalic acid content in order to improve its usability and healthiness as a more major source of food. Considering medicinal uses, it is clear that further investigations on different sorrel compounds are needed to show their true effect and provide scientific evidence 
for the medicinal effects of sorrel preparations and to aid the development of novel therapeutics and drug discovery. The applicability of sorrel for phytoremediation remains as a largely untouched research area.

Funding Information Open access funding provided by University of Helsinki including Helsinki University Central Hospital.

Open Access This article is licensed under a Creative Commons Attribution 4.0 International License, which permits use, sharing, adaptation, distribution and reproduction in any medium or format, as long as you give appropriate credit to the original author(s) and the source, provide a link to the Creative Commons licence, and indicate if changes were made. The images or other third party material in this article are included in the article's Creative Commons licence, unless indicated otherwise in a credit line to the material. If material is not included in the article's Creative Commons licence and your intended use is not permitted by statutory regulation or exceeds the permitted use, you will need to obtain permission directly from the copyright holder. To view a copy of this licence, visit http://creativecommons.org/licenses/by/4.0/.

\section{References}

Abbasi, A. M., M. H. Shah, T. Li, X. Fu, X. Guo \& R. H. Liu. 2015. Ethnomedicinal values, phenolic contents and antioxidant properties of wild culinary vegetables. Journal of Ethnopharmacology 162: 333-345.

Abbet, C., R. Mayor, D. Roguet, R. Spichiger, M. Hamburger \& O. Potterest. 2014. Ethnobotanical survey on wild alpine food plants in Lower and Central Valais (Switzerland). Journal of Ethnopharmacology 151: 624-634.

Ahmad, S., F. Ullah, A. Sadiq, M. Ayah, M. Imran, I. Ali, A. Zeb, F. Ullah \& M. R.Shah. 2016. Chemical composition, antioxidant and anticholinesterase potentials of essential oil of Rumex hastatus D. Don collected from the North West of Pakistan. BMC Complementary and Alternative Medicine 16: 29.

Ainsworth, C., A. Rahman, J. Parker \& G. Edwards. 2005. Intersex inflorescences of Rumex acetosa demonstrate that sex determination is unique to each flower. New Phytologist 165: 711-720.

Ali-Shtayeh, M. S., R. M. Jamous, J. H. Al-Shafie, W. A. Elgherabah, F. A. Kherfan, K. H. Qarariah, I. S. Khdair, I. M. Soos, A. A. Musleh, B. A. Isa, H. M.Herzallah, K. B. Khlaif, S. M. Aiash, G. M. Swaiti, M. A. Abuzahra, M. M. Haj-Ali, N. A. Saifi, H. K. Azem \& H. A. Nasrallah. 2008. Traditional knowledge of wild edible plants used in Palestine (Northern West Bank): a comparative study. Journal of Ethnobiology and Ethnomedicine 4: 13.

Alzoreky, N. S. \& K. Nakahara. 2001. Antioxidant activity of some edible Yemeni plants evaluated by ferrylmyoglobin/ABTS?+ assay. Food Science and Technology Reserach 7: 141-144.

Andersen, S. T. 1990. Pollen spectra from two early Neolithic lugged jars in the long barrow at Bjornsholm, Denmark. Journal of Danish Archaeology 9: 59-63.

Bae, J-Y., Y. S. Lee, S. Y. Han, E. J. Jeong, M. K. Lee, J. Y. Kong, D. H. Lee, K. J. Cho, H-S. Lee \& M.-J. Ahn. 2012. A comparison between water and ethanol extracts of Rumex acetosa for protective effects on gastric ulcers in mice. Biomolecules \& Therapeutics 20: 425-430.

Beckert, S. \& A Hensel. 2013. Proteinase-inhibiting activity of an extract of Rumex acetosa L. against virulence factors of Porphyromonas gingivalis. Planta Medica 79: PJ6. https://doi.org/10.1055/s-00331352210

Bello O. M., P. S. Fasinu, O. E. Bello, A. B. Ogbesejana, C. O. Adtunji, A. O. Dada, O. S. Ibitoye, S. Aloko \& O. S. Oguntoye. 2019. Wild vegetable Rumex acetosa Linn.: its ethnobotany, pharmacology and phytochemistry - a review. South African Journal of Botany 125: 149-160.

Bicker, J., F. Petereit \& A. Hensel. 2009. Proanthocyanidins and a phloroglucinol derivative from Rumex acetosa L. Fitoterapia 80: 483-495.

Błocka-Wandas M., E. Sliwinska, A. Grabowska-Joachimiak, K. Musial \& A. J. Joachimiak. 2007. Male gametophyte development and two different DNA classes of pollen grains in Rumex acetosa L., a plant with an XX/ XY1Y2 sex chromosome system and a female-biased sex ratio. Sexual Plant Reproduction 20: 171-180.

Cardon, D. 2007. Natural Dyes. Sources, Tradition, Technology and Science. Archetype Publications, London.

Ceccanti, C., M. Landi, L. Incrocci, A. Pardossi \& L. Guidi. 2020. Suitability of hydroponically-grown Rumex acetosa L. as fresh-cut produce. Horticulturae 2020, 6: 4. https://doi.org/10.3390/horticulturae6010004

Couplan, F. 2009. Le Regal Vegetal. Plantes Sauvages Comestibles. Encyclopedie des Plantes Comestibles de l'Europe. Éditions Sang de la Terre, Paris. 
Dogan, Y., A. Nedelcheva, Ł. Łuczaj, C. Dragulescu, G. Stefkov, A. Maglajlic, J. Ferner, N. Papp, A. Hajdari, B. Mustafa, Z. Dajc-Stevanovic \& A. Pieroni. 2015. Of the importance of a leaf: the ethnobotany of sarma in Turkey and the Balkans. Journal of Ethnobiology and Ethnomedicine 11: 26.

Demirezer, L. Ö., A. Kuruuzun-Uz, I. Bergere, H.-J. Schiewe \& A. Zeeck. 2001. The structures of antioxidant and cytotoxic agents from natural source: anthraquinones and tannins from roots of Rumex patientia. Phytochemistry 58: 1213-1217.

Derksen, A., A. Hensel, W. Hafezi, F. Herrmann, T. J. Schmidt, C. Ehrhardt, S. Ludwig \& J. Kühn. 2014. 3O-galloylated procyanidins from Rumex acetosa L. inhibit the attachment of influenza A virus. PLOS ONE 9(10): e110089. https://doi.org/10.1371/journal.pone.0110089

Ernst W. H. O., F. Knolle, S. Kratz \& E. Schnug. 2004. Aspects of ecotoxicology of heavy metals in the Harz region - a guided excursion. Lanbauforschung Völkenrode 54: 53-71.

Etkin, N. L. 1994. The Cull of the Wild, in: Eating on the Wild Side - The Pharmacologic, Ecologic and Social Implication on Using Noncultigens, (ed. N. L. Etkin) Arizona University Press, Tuscon.

Flora Europaea. 1993. Volume 1: Lycopodiaceae to Platanaceae. Eds. T. G. Tutin, V. H. Heywood, N. A. Burges, D. H. Valentine, S. M. Walters \& D. A. Webb. The Cambridge University Press, Cambridge, UK.

Gescher, K., A. Hensel, W. Hafezi, A. Derksen \& J. Kuhn. 2011. Oligomeric proanthocyanidins from Rumex acetosa L. inhibit the attachment of herpes simplex virus type-1. Antiviral Research 89: 9-18.

Glatthaar-Saalmüller, B., U. Rauchhaus, S. Rode, J. Haunschild \& A. Saalmüller. 2011. Antiviral activity in vitro of two preparations of the herbal medicinal product Sinupret ${ }^{\circledR}$ against viruses causing respiratory infections. Phytomedicine 19: 1-7.

Grant S., A. Houben, B. Vyskot, J. Siroky, W-H. Pan, J. Mackas \& H. Saedler. 1994. Genetics of sex determination in flowering plants. Developmental Genetics 15: 214-230.

Gupta, K. C., P Gupta, P Singh, S. V. Singh \& S. Agarwal. 2006. Chemistry of natural dyes. In: M. Daniel, S. D. Bhattacharya, A. Arya \& V. M. Raole (eds). Natural Dyes: Scope and Challenges, pp. 7-34. Scientific Publishers, Jodhpur, India.

Hussain, M., S. M. Raza \& H. J. Khalid. 2015. Pharmacologically mechanistic basis for the traditional uses of Rumex acetosa in gut motility disorders and emesis. Bangladesh Journal of Pharmacology 10: 548-554.

Ito, H. 1986. Effects of the antitumor agents from various natural sources on drug-metabolizing system, phagocytic activity and complement system in sarcoma 180-bearing mice. Japanese Journal of Pharmacology 40: 435-443.

Jarić, S, Z. Popović, M. Mačukanović-Jocić, L. Djurdjević, M. Mijatović, B. Karadžić, M. Mitrović \& P. Pavlović. 2007. An ethnobotanical study on the usage of wild medicinal herbs from Kopaonik Mountain (Central Serbia), Journal of Ethnopharmacology 111: 160-175.

Jund, R., M. Mondigler, H. Steindl, H. Stammer, P. Stierna \& C. Bachert. 2012. Clinical efficacy of a dry extract of five herbal drugs in acute viral rhinosinusitis. Rhinology 50: 417-426.

Khan, S. W. \& S. Khatoon. 2008. Ethnobotanical studies on some useful herbs of Haramosh and Bugrote valleys in Gilgit, northern areas of Pakistan. Pakistan Journal of Botany 40: 43-58.

Kihara, H. \& T. Ono. 1923. Cytological studies on Rumex L., I. Chromosomes of Rumex acetosa L. Botanical Magazine Tokyo 37: 84-90.

Korpelainen, H. 1991. Sex ratio variation and spatial segregation of the sexes in populations of Rumex acetosa and $R$. acetosella (Polygonaceae). Plant Systematics and Evolution 174: 183-195.

Korpelainen, H. 1992. Patterns of resource allocation in male and female plants of Rumex acetosa and R. acetosella. Oecologia 89: 133-139.

Korpelainen, H. 1993. Phenological differentiation between populations and sexes in the perennial species Rumex acetosa. Acta Oecologica 14: 287-297.

Korpelainen, H. 1998. Labile sex expression in plants. Biological Reviews 73: 157-180.

Korpelainen, H. 1999. Genetic differentiation in the outcrossed, widespread and wind-pollinated species, Rumex acetosa (Polygonaceae). Botanisches Jahrbücher für Systematik, Pflanzengeschichte und Pflanzengeographie 121: 269-277.

Korpelainen, H. 2002. A genetic method to resolve gender complements investigations on sex ratios in Rumex acetosa. Molecular Ecology 11: 2151-2156.

Kota S., P. Dumpala, R. K. Anantha, M. K. Verma \& S. Kandepu. 2017. Evaluation of therapeutic potential of the silver/silver chloride nanoparticles synthesized with the aqueous leaf extract of Rumex acetosa. Nature Research, Scientific Report 7: 11566. https://doi.org/10.1038/s41598-017-11853-2

Kotzamani, G. \& A. Livarda. 2018. People and plant entanglements at the dawn of agricultural practice in Greece. An analysis of the Mesolithic and early Neolithic archaeobotanical remains. Quaternary International 496: 80-101.

Kubiak-Martens, L. 1999. The plant food component of the diet at the late Mesolithic (Ertebolle) settlement at Tybrind Vig, Denmark. Vegetation History and Archaeobotany 8: 117-127. 
Kucekova Z., J. Mlcek, P. Humpolicek, O. Rop, P. Valasek \& P. Saha. 2011. Phenolic compounds from Allium schoenoprasum, Tragopogon pratensis and Rumex acetosa and their antiproliferative effects. Molecules 16: 9207-9217.

Ladeji O. \& Z.S.C. Okoye. 1993. Chemical analysis of sorrel leaf (Rumex acetosa). Food Chemistry 48: 205-206.

Lee N-J., J-H. Choi, B-S. Koo, S-Y. Ryu, Y-H. Han, S-J. Lee \& D-U Lee. 2005. Antimutagenicity and cytotoxicity of the constituents from the aerial parts of Rumex acetosa. Biological and Pharmaceutical Bulletin 28: 2158-2161.

Liddell, H.G. \& Scott, R. 1940. Greek English Lexicon. 9th Edition. Oxford University Press. Lloyd, D.G. 1982. Selection of combined versus separate sexes in seed plants. The American Naturalist 120: 571-585.

Lloyd, D.G. 1982. Selection of combined versus separate sexes in seed plants. The American Naturalist 120: 571-585.

Łuczaj, Ł. \& W. M. Szymański. 2007. Wild vascular plants gathered for consumption in the Polish countryside: a review. Journal of Ethnobiology and Ethnomedicine 3: 17. 10.1186/1746-4269-3-17

Mabberley, D. J. 2008. Mabberley's Plant-Book. $3^{\text {rd }}$ Edition. The Cambridge University Press, Cambridge

Makarov, V., S. Makarova, A. J. Love, O. Sinitsyna, A. O. Dudnik, I.V. Yaminsky, M. E. Taliansky \& N. O. Kalinina. 2014. Biosynthesis of stable iron oxide nanoparticles in aqueous extracts of Hordeum vulgare and Rumex acetosa plants. Langmuir 30: 5982-5988.

Mantle, D., F. Eddeb \& A. T. Pickering. 2000. Comparison of relative antioxidant activities of British medicinal plant species in vitro. Journal of Ethnopharmacology 72: 47-51.

Manzano S., Z. Megías, C. Martínez, A. García, E. Aguado, T. Chileh, D. López-Alonso, F. García-Maroto, E. Kejnovský, J. Široký, Z. Kubát, T. Králová, B. Vyskot \& M. Jamilena. 2017. Overexpression of a flowerspecific aerolysin-like protein from the dioecious plant Rumex acetosa alters flower development and induces male sterility in transgenic tobacco. The Plant Journal 89: 58-72.

Mariotti B., S. Manzano, E. Kejnovský, B. Vyskot \& M. Jamilena. 2009. Accumulation of Y-specific satellite DNAs during the evolution of Rumex acetosa sex chromosomes. Molecular Genetics and Genomics 281: 249. https://doi.org/10.1007/s00438-008-0405-7

Matsuhisa S. \& A. Ushimaru. 2019. Does sexual dimorphism exist in flowering phenology traits in anemophilous dioecious species? A test with Rumex acetosa. American Journal of Botany 106: 1356-1364.

Mattalia, G., C. L. Quave \& A. Pieroni. 2013. Traditional uses of wild food and medicinal plants among Brigasc, Kyé, and Provençal communities on the Western Italian Alps. Genetic Resources and Crop Evolution 60: 587-603.

McLain, R. J., P. T. Hurley, M. R. Emery \& M. R. Poe. 2014. Gathering "wild” food in the city: rethinking the role of foraging in urban ecosystem planning and management. The International Journal of Justice and Sustainability 19: 220-240.

Mekonnen, T., K. Urga \& E. Engidawork. 2010. Evaluation of the diuretic and analgesic activities of the rhizomes of Rumex abyssinicus Jacq. in mice. Journal of Ethnopharmacology 127: 433-439.

Navajas-Pérez, R., R. de la Herrán, G. López González, M. Jamilena, R. Lozano, C.R. Rejon, M. R. Rejon \& M. A. Garrido-Ramos. 2005. The evolution of reproductive systems and sex-determining mechanisms within Rumex (Polygonaceae) inferred from nuclear and chloroplastidial sequence data. Molecular Biology and Evolution 2: 1929-1939.

Nedelcheva, A. 2013. An ethnobotanical study of wild edible plants in Bulgaria. EurAsian Journal of BioSciences 7: 7-94.

Noonan, S. C. \& G. P. Savage. 1999. Oxalate content of foods and its effect on humans. Asia Pacific Journal of Clinical Nutrition 8: 64-74.

Ono, T. 1935. Chromosomen und Sexualität von Rumex acetosa. Science Reports of Tohoku Imperial University IV 10: 41-210.

Pardo de Santayana, M., J. Tardio, E. Blanco, A. M. Carvalho, J. J. Lastra, E. San, M. Morales \& R. Morales. 2007. Traditional knowledge of wild edible plants used in the northwest of the Iberian Peninsula (Spin and Portugal): a comparative study. Journal of Ethnobiology and Ethnomedicine 3: 1-11.

Parker, J. S. 1990. Sex-chromosome and sexual differentiation in flowering plants. Chromosomes Today 10: 187-198.

Parker, J. S., M. S. Clark. 1991. Dosage sex chromosome systems in plants. Plant Science 80: 79- 92.

Parker, P. 2018. A Little Book of Latin for Gardeners. Little, Brown, London.

Pereira, C., L. Barros, A. M. Carvalho \& C. F. R. Ferreira. 2013. Use of UFLC-PDA for the analysis of organic acids in thirty-five species of food and medicinal plants. Food Analytical Methods 6: 1337-1344.

Pieroni, A., K. Cianfaglione, A. Nedelcheva, A. Hajdari, B. Mustafa \& C.L. Quave. 2014. Resilience at the border: traditional botanical knowledge among Macedonians and Albanians living in Gollobordo, Eastern Albania. Journal of Ethnobiology and Ethnomedicine 10: 31. https://doi.org/10.1186/1746-4269-10-31 
Pieroni, A., \& M. E. Giusti. 2009. Alpine ethnobotany in Italy: traditional knowledge of gastronomic and medicinal plants among the Occitans of the upper Varaita valley, Piedmont. Journal of Ethnobiology and Ethnomedicine 5: 32. https://doi.org/10.1186/1746-4269-5-32

Qamar, H. M. U. D., R. Qayyum, U. Salma, S. Khan, T. Khan \& A. J. Shah. 2018. Vascular mechanisms underlying the hypotensive effect of Rumex acetosa. Pharmaceutical Biology 56: 225-234.

Qureshi, R. A., M. A. Ghufran, K. N. Sultana, M. Ashraf \& A. G. Khan. 2007. Ethnomedicinal studies of medicinal plants of Gilgit district and surrounding areas. Ethnobotany Research Applications 5: 115-122.

Saleh, N., M. N. El-Hadidi \& R. F. M. Arafa. 1993. Flavonoids and anthraquinones of some Egyptian Rumex species (Polygonaceae). Biochemical Systematics and Ecology 21: 301-303.

Samancioglu, A., I. G. Sat, E. Yildirim, S. Ercisli, T. Jurikova \& J. Mlcek. 2016. Total phenolic and vitamin C content and antiradical activity evaluation of traditionally consumed wild edible vegetables from Turkey. Indian Journal of Traditional Knowledge 15: 208-213.

Schmuch, J. M., S. Beckert \& A. Hensel. 2013. Proanthocyanidins from Rumex acetosa L. increase the in vitro rate of phagocytosis of Porphyromonas gingivalis in murine macrophages and provide a cytoprotective and anti-inflammatory potential for modern periodontitis therapy. Planta Medica 79 - SL15.

Shibata, F., M. Hizume \& Y. Kuroki. 1999. Chromosome painting of Y chromosomes and isolation of a Y chromosome-specific repetitive sequence in the dioecious plant Rumex acetosa. Chromosoma 108: 266-270.

Shibata, F., M. Hizume \& Y. Kuroki. 2000. Differentiation and the polymorphic nature of the Y chromosomes revealed by repetitive sequences in the dioecious plant, Rumex acetosa. Chromosome Research 8: 229-236.

Sõukand, R. \& A. Pieroni. 2019. Resilience in the mountains: biocultural refugia of wild food in the Greater Caucasus Range, Azerbaijan. Biodiversity and Conservation 28: 3529-3545.

Sun, Y. Y., X. H. Su \& J. Y. Jin. 2015. Rumex acetosa L. induces vasorelaxation in rat aorta via activation of PI3-kinase/Akt- AND Ca2+-eNOS-NO signaling in endothelial cells. Journal of Physiology and Pharmacology 66: 907-915.

Tamokou de Dieu J., J. R. Chouna, E. Fischer-Fodor, G. Cherches, O. Barbos, D. Benedec, M. Duma, A. P. N. Efouet, H. K. Wabo, J. R. Kuiate, A. Mot \& R. Silaghi-Rumitrescu. 2013. Anticancer and antimicrobial activities of some antioxidant-rich Cameroonian medicinal plants. PLoS ONE 8(2): e55880. https://doi. org/10.1371/journal.pone.0055880

Tanaka, T. 1976. Tanaka's Cyclopedia of Edible Plants of the World. Keigaku Publishing, Tokyo.

Taylor, R. S. L., F. Edel, N. P. Manandhar \& G. H. N. Towers. 1996. Antimicrobial activities of southern Nepalese medicinal plants. Journal of Ethnopharmacology 50: 97-102

Tolrà, R. P., C. Poschenrieder, B. Luppi \& J. Barcelo. 2005. Aluminium-induced changes in the profiles of both organic acids and phenolic substances underlie Al tolerance in Rumex acetosa L. Environmental and Experimental Botany 54: 231-238.

Tuazon-Nartea, J., G. Savage. 2013. Investigation of oxalate levels in sorrel plant parts and sorrel-based products. Food and Nutrition Sciences 4: 838-843.

Vanhanen, S. \& P. Pesonen. 2016. Wild plant gathering in Stone Age Finland. Quaternary International 404, A: $43-55$.

Vasas, A,, O. Orbán-Gyupai \& J. Hohmann. 2015. The genus Rumex. Review of traditional uses, phytochemistry and pharmacology. Journal of Ethnopharmacology 175:198-228.

Wang, Q. R., Y. S. Cui, X. Liu, Y. T. Dong \& P. Christie. 2003. Soil contamination and plant uptake of heavy metals at polluted sites in China. Journal of Environmental Science and Health A, 38:823-838.

Weaver, W. W. 2000. 100 Vegetables and Where They Came From. Algonquin Books of Chapel Hill, Chapel Hill, NC, USA.

Wegiera, M., H. D. Smolarz, D. Wianowska \& A. L. Dawidowicz. 2007. Anthracene derivatives in some species of Rumex L. genus. Acta Societatis Botanicorum Poloniae 76:103-108.

Wegiera, M., H. D. Smolarz \& A. Bogucka-Kocka. 2012. Rumex L. species induce apoptosis in 1301, EOL-1 AND H-9 cell lines. Acta Poloniae Pharmaceutica - Drug Research, 69:487-499.

WFO. 2020. World Flora Online. Published on the Internet; http://www.worldfloraonline.org. Accessed on July 1,2020 .

Xiong, J. 1998. Use of hybrid Rumex acetosa L. in production of wheat flour-containing product. Patent WO1999057984A1.

Ye, M., B. Liao, J. T. Li, A. Mengoni, M. Lu, W. C. Luo \& W. S. Shu. 2012. Contrasting patterns of genetic divergence in two sympatric pseudo-metallophytes: Rumex acetosa L. and Commelina communis L. BMC Evolutionary Biology 12:84.

Zhou, X. H., G. X. Wang \& F. Yang. 2012. Nitrogen removal from eutrophic river waters by using Rumex acetosa cultivated in ecological floating beds. Fresenius Environmental Bulletin 21:1920-1928. 